\title{
Quantification of naive and memory T-cell turnover during HIV-1 infection
}

\author{
Nienke Vrisekoop ${ }^{a, *}$, Julia Drylewicz ${ }^{\mathrm{a}, \mathrm{b}, *}$, Rogier Van Gent ${ }^{\mathrm{a}, \mathrm{c}, *}$,

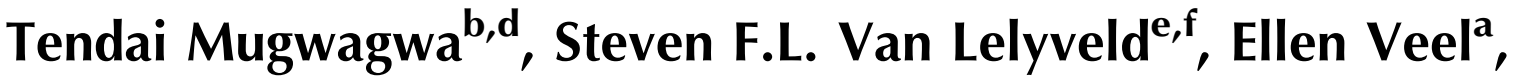 \\ Sigrid A. Otto ${ }^{a}$, Mariëtte T. Ackermans ${ }^{g}$, Joost N. Vermeulen ${ }^{\text {h,i }}$, \\ Hidde H. Huidekoper', Jan M. Prins', Frank Miedema ${ }^{\mathrm{a}}$, \\ Rob J. de Boer ${ }^{b, *}$, Kiki Tesselaar ${ }^{a, *}$ and José A.M. Borghans ${ }^{a, *}$
}

\begin{abstract}
Background: In HIV infection, the homeostasis of $\mathrm{CD}^{+}$and $\mathrm{CD} 8^{+} \mathrm{T}$ cells is dramatically disturbed, and several studies have pointed out that $\mathrm{T}$-cell turnover rates are increased. To understand how the $\mathrm{CD}^{+}$and $\mathrm{CD}^{+}{ }^{+} \mathrm{T}$-cell pools are affected, it is important to have quantitative insights into the lifespans of the cells constituting the different T-lymphocyte populations.
\end{abstract}

Methods: We used long-term in-vivo ${ }^{2} \mathrm{H}_{2} \mathrm{O}$ labeling and mathematical modeling to estimate the average lifespans of naive and memory $\mathrm{CD}^{+}$and $\mathrm{CD}^{+}{ }^{+}$cells in untreated $(n=4)$ and combination antiretroviral therapy-treated $(n=3)$ HIV-1-infected individuals.

Results: During untreated chronic HIV-1 infection, naive $\mathrm{CD} 4^{+}$and $\mathrm{CD} 8^{+} \mathrm{T}$ cells lived on average 618 and 271 days, whereas memory $\mathrm{CD}^{+}$and $\mathrm{CD} 8^{+} \mathrm{T}$ cells had average lifespans of 53 and 43 days, respectively. These lifespans were at least three-fold shorter than those in healthy controls $(n=5)$. In patients on effective combination antiretroviral therapy with total $\mathrm{CD} 4^{+} \mathrm{T}$-cell counts in the normal range, we found that naive $\mathrm{CD} 4^{+}$ and $\mathrm{CD}^{+}{ }^{+} \mathrm{T}$-cell lifespans had not completely normalized and were still two-fold shortened.

Conclusion: The average lifespan of both naive and memory $\mathrm{CD} 4^{+}$and $\mathrm{CD} 8^{+} \mathrm{T}$ cells decreased during untreated chronic HIV-1 infection. Although the turnover of the memory T-cell populations nearly normalized during effective treatment, the turnover of naive $\mathrm{CD}^{+}$and $\mathrm{CD}^{+} \mathrm{T}$ cells did not seem to normalize completely.

Copyright (c) 2015 Wolters Kluwer Health, Inc. All rights reserved.

AIDS 2015, 29:2071-2080

Keywords: HIV, labeling, lifespan, lymphocytes, mathematical modeling, stable isotope, $\mathrm{T}$ cells

\footnotetext{
a Laboratory of Translational Immunology, Department of Immunology, University Medical Center Utrecht, ${ }^{\mathrm{b}}$ Theoretical Biology and Bioinformatics, Utrecht University, Utrecht, ' ${ }^{\mathrm{C}}$ Department of Gastroenterology and Hepatology, Erasmus MC Rotterdam, Rotterdam, The Netherlands, ${ }^{\mathrm{d}}$ Department of Infectious Disease Epidemiology, Imperial College, London, UK, e Department of Internal Medicine and Infectious Diseases, University Medical Center Utrecht, Utrecht, ${ }^{\mathrm{f}}$ Department of Internal Medicine and Gastroenterology, Kennemer Gasthuis, Haarlem, 'D Department of Clinical Chemistry, Laboratory of Endocrinology, Academic Medical Center, 'IATEC, Academic Medical Center, 'Department of Internal Medicine, Academic Medical Center, and 'Department of Pediatrics, Academic Medical Center, Amsterdam, The Netherlands.

Correspondence to Dr José A.M. Borghans, Laboratory of Translational Immunology, Department of Immunology, Utrecht Medical Center Utrecht, WKZ Room KC.02.085.2, P.O. Box 85090, 3508 AB Utrecht, The Netherlands.

Tel: +31 887554 275; e-mail: J.Borghans@umcutrecht.nl

* Nienke Vrisekoop, Julia Drylewicz, Rogier Van Gent contributed equally to this study; Rob J. de Boer, Kiki Tesselaar, José A.M. Borghans also contributed equally to this study.

Received: 22 April 2015; revised: 15 July 2015; accepted: 15 July 2015.
} 


\section{Introduction}

The homeostasis of the $\mathrm{CD}^{+}$and $\mathrm{CD} 8^{+}{ }^{-}$-cell pools is clearly disturbed in HIV infection. Although the causes of these changes are still debated, there is ample evidence that the state of chronic immune activation induced by HIV plays a key role in disease progression [1-5]. Several studies have shown faster kinetics of $\mathrm{CD} 4^{+}$and $\mathrm{CD}^{+} \mathrm{T}$ cells during HIV-1 infection, measured by different labeling techniques or markers for T-cell proliferation $[6-14]$. These increased turnover rates are not merely due to shifts in the percentages of naive and memory $\mathrm{T}$ cells [15], because studies in separated naive and memory T-cell populations have shown that both naive and memory $\mathrm{CD}^{+}$and $\mathrm{CD} 8^{+} \mathrm{T}$ cells are turning over more rapidly in HIV-1-infected individuals $[16,14]$. To understand how these changes in T-cell turnover relate to the disturbed lymphocyte homeostasis in HIV-1 infection, it is important to have quantitative insights into T-cell dynamics in healthy and HIV-1-infected individuals. Only once such quantitative insights are available, can one estimate, for example, the expected effect of impaired thymic output on $\mathrm{CD} 4^{+}$T-cell loss in HIV-1 infection (Drylewicz et al. submitted).

Quantitative insights into T-cell lifespans are extremely scarce because of the difficulty to measure cellular turnover rates under normal physiological circumstances. Markers that have been used to quantify T-cell dynamics include Annexin-V staining of cells undergoing apoptosis, and measurement of the expression of Ki67, an intracellular marker that is uniquely expressed during the G1, S, G2, and mitotic phase of the cell cycle. Such snapshot markers are, however, hard to translate into the actual parameters of interest, that is, the fraction of cells that die or proliferate per day. It has even been suggested that $\mathrm{T}$ cells undergoing proliferation in HIV-infected individuals can get arrested in the cell cycle [17], and hence the fraction of Ki67-expressing cells would exceed the fraction of cells that are actually producing progeny. The introduction of stable isotope labeling into the field of immunology has paved the way for reliable quantification of T-cell dynamics. Previous studies based on ${ }^{2} \mathrm{H}-$ glucose or ${ }^{2} \mathrm{H}_{2} \mathrm{O}$ labeling demonstrated the great potential of this technique for studying lymphocyte turnover $[7,9,11,12,16,18-24]$.

Using deuterated water $\left({ }^{2} \mathrm{H}_{2} \mathrm{O}\right)$ labeling, we compared the average lifespans and total daily production rates (i.e. numbers of cells produced per day) of naive and memory $\mathrm{CD}^{+}$and $\mathrm{CD}^{+} \mathrm{T}$ cells in treatment-naive chronic HIV-1-infected individuals and in combination antiretroviral therapy (cART)-treated HIV-1-infected individuals, and compared them with healthy controls. Mathematical analysis of the 9-week up-labeling and 16-week down-labeling curves revealed that the average lifespans of not only memory but also naive $\mathrm{CD} 4^{+}$and $\mathrm{CD}^{+} \mathrm{T}$ lymphocytes were at least three-fold shortened during untreated HIV-1 infection. Despite good reconstitution of the $\mathrm{CD}^{+}{ }^{+}$T-cell pool in cART-treated patients, their dynamics of naive $\mathrm{CD} 4^{+}$and $\mathrm{CD} 8^{+} \mathrm{T}$ cells remained affected. We discuss the implications of these quantitative changes for the different mechanisms that are held responsible for the changes in the T-cell population that are typically observed in HIV-1-infected individuals.

\section{Material and methods}

\section{Participants and in vivo ${ }^{2} \mathrm{H}_{2} \mathrm{O}$ labeling protocol}

Seven HIV-1-infected male individuals were enrolled in the study after having provided written informed consent. Four of them were included via the Academic Medical Center (Amsterdam, The Netherlands) and were treatment-naive at inclusion and did not receive antiretroviral therapy during the whole protocol (Centers for Disease Control class A). Patient B experienced bronchitis (diagnosed and treated by the general practitioner), which started a few days prior to the second visit at day 22. Patient $\mathrm{C}$ withdrew from the protocol from day 113 onward, because he was advised to start treatment, and developed a disseminated Varicella shortly after withdrawal. Patient D developed gastroenteritis (light fever and diarrhea) a few days prior to the visit at day 63. The other three HIV-infected patients had received cART treatment for at least 1 year at inclusion and were included via the University Medical Center Utrecht (the Netherlands). At inclusion, all three patients had more than 350 $\mathrm{CD}^{+}{ }^{+}$T-cell counts/ $\mu$ l blood, successful viral suppression $(<50$ copies $/ \mathrm{ml})$ and a maximal treatment interruption of 2 weeks within the 6 months prior to inclusion. Details about the HIV-infected patients are shown in Table 1. This study was approved by the medical ethical committees of the AMC and UMC Utrecht and written informed consent was obtained from all participants [22].

We have studied T-cell dynamics of healthy volunteers before, and reported that naive $\mathrm{T}$ cells have a life expectancy of 6-10 years [22]. Because these life expectancies by far exceed the duration of a labeling study, we here extended these analyses by measuring deuterium enrichment in blood samples taken approximately 3 years after stop of label administration.

All individuals drank $1.25 \mathrm{ml} / \mathrm{kg}$ body water daily for 9 weeks. Body water was assumed to be $60 \%$ of body weight [25]. All individuals received an initial bolus of ${ }^{2} \mathrm{H}_{2} \mathrm{O}$ in small portions throughout the first day [26]. In individuals who experienced nausea or dizziness the initial bolus was reduced; this did not affect the interpretation of the labeling curves because actual deuterium availability was closely monitored from urine. Blood and urine were collected before labeling (blood), at the end of the first labeling day (urine), four to six times during the rest of the 9-week labeling phase, and five to seven times during the down-label phase of 16 weeks. 


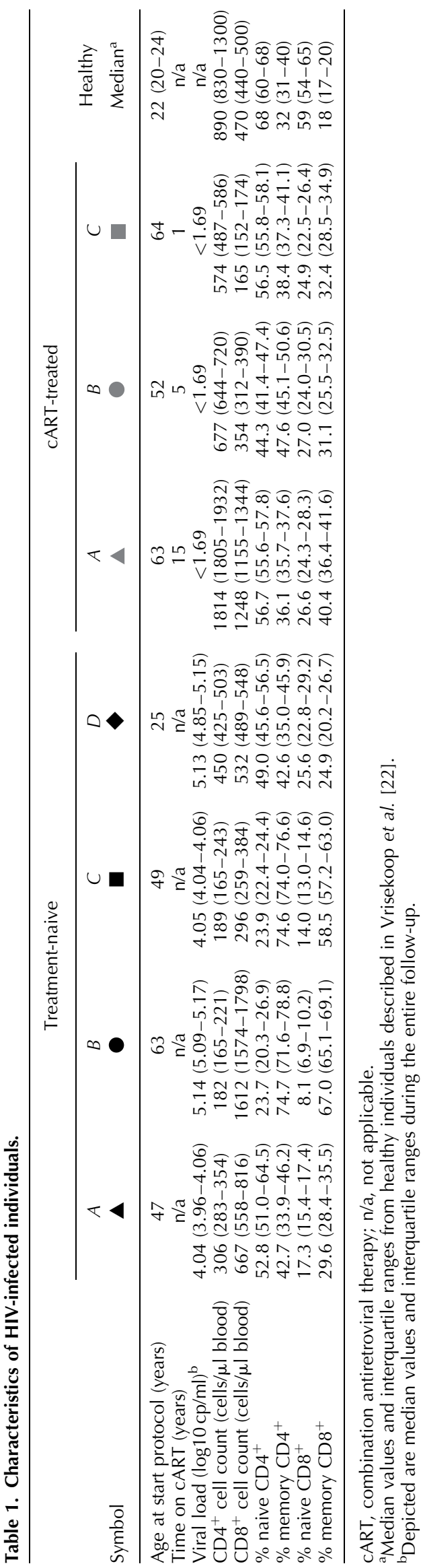

The label enrichment in urine was used to correct for the actual availability of deuterium for the different cell populations at any point in time (Fig. S1, http:// links.lww.com/QAD/A760) [22]. The enrichment curves of all T-cell populations were normalized to the estimated maximum level of label incorporation in peripheral blood granulocytes (Fig. S1, http://links.lww. com/QAD/A760), a cell population that is thought to turnover completely during the labeling period [27].

\section{Flow cytometry and cell sorting}

Absolute $\mathrm{CD}^{+}{ }^{+}$and $\mathrm{CD} 8^{+}$T-cell counts were determined by dual-platform flow cytometry. Peripheral blood mononuclear cells were obtained by Ficoll-Paque density gradient centrifugation from heparinized blood and cryopreserved until further processed. To measure the fraction of labeled cells within the naive $\left(\mathrm{CD} 45 \mathrm{RO}^{-} \mathrm{CD} 27^{+}\right)$and memory $\left(\mathrm{CD} 45 \mathrm{RO}^{+}\right) \mathrm{CD}^{+}$and $\mathrm{CD}^{+}{ }^{+}$-cell population, these subsets were isolated by cell sorting on a BD FACSAria as previously described [22]. Purity of the sorted cells was on average $99.2 \%$ for naive $\mathrm{CD}^{+}, 98.7 \%$ for naive $\mathrm{CD}^{+} \mathrm{T}$ cells, $98.1 \%$ for memory $\mathrm{CD} 4^{+} \mathrm{T}$ cells and 97.1\% for memory $\mathrm{CD}^{+} \mathrm{T}$ cells.

\section{DNA isolation}

Genomic DNA was isolated from granulocytes, total peripheral blood mononuclear cells $(t=0)$ and sorted cells using the Blood QuickPure kit (Macherey-Nagel, Dueren, Germany) or the Reliaprep Blood gDNA Miniprep System (Promega, Madison, Wisconsin, USA), and stored at $-20^{\circ} \mathrm{C}$ before processing for gas chromatography/mass spectrometry.

\section{Measurement of ${ }^{2} \mathrm{H}_{2} \mathrm{O}$ enrichment in body water and DNA}

Deuterium enrichment in urine was measured by a method adopted from Previs et al. [28]. The isotopic enrichment of DNA was measured according to the method described by Neese et al. [27] with minor modifications [22].

\section{Statistical analyses}

A likelihood ratio test was used to determine whether the data were significantly better described by a model with kinetic heterogeneity. Differences in expected lifespans and total production rates of T-cell subsets between healthy volunteers and HIV-infected individuals were tested using a Mann-Whitney test. Statistical analyses were performed using $\mathrm{R}$ and Graphpad. Differences with $P<0.05$ were considered significant.

\section{Results}

Patient characteristics and labeling

HIV-1 viral loads of the untreated HIV-1-infected individuals were relatively constant during the labeling protocol and varied from $10^{4}$ to $10^{5}$ copies $/ \mathrm{ml}$ between 
individuals (Table 1). In patients on cART, viral loads were undetectable throughout the study. During the entire protocol, absolute $\mathrm{CD} 4^{+}$and $\mathrm{CD} 8^{+}$T-cell counts and fractions of naive and memory $\mathrm{CD} 4^{+}$and $\mathrm{CD} 8^{+} \mathrm{T}$ cells remained almost constant in all HIV-1 patients (data not shown). Absolute CD4 ${ }^{+}$T-cell counts in untreated patients ranged between 180 and 450 cells/ $\mu$ l blood, which was $\sim 3$.5-fold lower than in healthy volunteers, whereas in cART-treated patients they were in the normal range. The percentages of naive $\mathrm{CD} 4^{+}$and $\mathrm{CD} 8^{+}$ $\mathrm{T}$ cells were reduced in untreated HIV-1 infection: about two-fold for $\mathrm{CD}^{+}$and four-fold for $\mathrm{CD} 8^{+} \mathrm{T}$ cells. In cART-treated patients, percentages of naive $T$ cells were also reduced (about two-fold), especially in the naive $\mathrm{CD}^{+}{ }^{+}$T-cell pool (Table 1).

T-cell turnover rates were determined by analyzing the level of deuterium enrichment in the DNA of the naive and memory T-cell populations during and after 9-week administration of ${ }^{2} \mathrm{H}_{2} \mathrm{O}$ (see Methods), and by fitting a mathematical model that allows for kinetic heterogeneity within subpopulations [29,30] (see Supplemental Methods, http://links.lww.com/QAD/A760).

\section{Naive $\mathrm{CD4}^{+}$and $\mathrm{CD8}^{+}$T-cell turnover in healthy volunteers}

When we previously measured T-lymphocyte turnover rates in five healthy volunteers by ${ }^{2} \mathrm{H}_{2} \mathrm{O}$ labeling, we found that both $\mathrm{CD}^{+}$and $\mathrm{CD}^{+}{ }^{+}$naive $\mathrm{T}$ cells are extremely long-lived; during the down-labeling phase of 16 weeks we observed no significant loss of label from the naive T-cell populations, and we reported average lifespans of 6 and 9 years, respectively [22]. Because these life expectancies by far exceeded the duration of the labeling experiment, we approached four of the healthy volunteers to donate blood approximately 3 years after label cessation to be able to study whether label was still present. We found that indeed, even 3 years after label cessation, labeled DNA could still be detected in the naive T-cell pools of these individuals. The enrichment levels measured were perfectly in line with what we predicted when fitting the mathematical model to the previously published data only. Because the new samples were measured years after the published ones, we made sure that their label enrichment levels could be compared fairly by measuring them along with some earlier samples.

Fitting the complete dataset of the healthy individuals yielded little statistical evidence for kinetic heterogeneity in the naive T-cell pool $(P=0.09)$, that is, the labeling kinetics of the naive T-cell pool could be described well by a model in which all naive $\mathrm{T}$ cells had the same turnover rate (Fig. S2, http://links.lww.com/QAD/ A760). The fits described both the early and the late data points very well (Fig. S2, http://links.lww.com/ $\mathrm{QAD} / \mathrm{A} 760$ ), strengthening our previous conclusion [22] that naive $\mathrm{T}$ cells in healthy adults undergo very little turnover, with expected lifespans of 5.6 and 8.8 years for $\mathrm{CD}^{+}{ }^{+}$and $\mathrm{CD} 8^{+} \mathrm{T}$ cells, respectively (Table 2 ), and form a kinetically homogeneous population.

\section{$\mathrm{CD4}^{+}$and $\mathrm{CD8}^{+}$T-cell turnover in treatment- naive and combination antiretroviral therapy- treated HIV-infected individuals}

After 9 weeks of ${ }^{2} \mathrm{H}_{2} \mathrm{O}$ administration, not only memory but also naive $\mathrm{T}$ cells from treatment-naive HIV-infected

Table 2. Average per capita turnover rates ( $p$ per day) of the T-cell subsets of healthy individuals, treatment-naive and combination antiretroviral therapy-treated HIV-1-infected individuals.

\begin{tabular}{|c|c|c|c|c|c|c|}
\hline & & \multirow[b]{2}{*}{ Symbol } & \multicolumn{2}{|c|}{ Naive } & \multicolumn{2}{|c|}{ Memory } \\
\hline & & & $\mathrm{CD}^{+}$ & $\mathrm{CD}^{+}$ & $\mathrm{CD}^{+}$ & $\mathrm{CD}^{+}$ \\
\hline \multirow[t]{7}{*}{ Healthy $^{a}$} & A & $\triangle$ & $0.0011(0.0008-0.0015)^{\mathrm{b}}$ & $0.0006(0.0004-0.0009)$ & $0.0141(0.0105-0.0289)$ & $0.0108(0.0035-0.0213)$ \\
\hline & B & 0 & $0.0005(0.0003-0.0008)$ & $0.0002(0.0001-0.0004)$ & $0.0079(0.0062-0.0153)$ & $0.0084(0.0055-0.0181)$ \\
\hline & $\mathrm{C}$ & $\square$ & $0.0003(0.0002-0.0005)$ & $0.0001(0.0000-0.0004)$ & $0.0035(0.0025-0.0103)$ & $0.0110(0.0057-0.0280)$ \\
\hline & $\mathrm{D}$ & $\diamond$ & $0.0004(0.0002-0.0006)$ & $0.0003(0.0002-0.0005)$ & $0.0020(0.0014-0.0081)$ & $0.0064(0.0026-0.0800)$ \\
\hline & $\mathrm{E}$ & $\nabla$ & $0.0006(0.0003-0.0008)$ & $0.0004(0.0003-0.0006)$ & $0.0061(0.0048-0.0098)$ & $0.0048(0.0028-0.0133)$ \\
\hline & Median & & 0.0005 & 0.0003 & 0.0061 & 0.0084 \\
\hline & Lifespan $^{c}$ & & 2000 & 3333 & 164 & 119 \\
\hline \multirow[t]{6}{*}{ Treatment-naive } & A & $\Delta$ & $0.0023(0.0015-0.0033)$ & $0.0017(0.0009-0.0031)$ & $0.0190(0.0139-0.0290)$ & $0.0124(0.0081-0.0319)$ \\
\hline & B & & $0.0024(0.0016-0.0034)$ & $0.0038(0.0031-0.0048)$ & $0.0186(0.0150-0.0245)$ & $0.0140(0.0103-0.0426)$ \\
\hline & C & E & $0.0010(0.0005-0.0016)$ & $0.0036(0.0024-0.0054)$ & $0.0291(0.0148-0.1208)$ & $0.0328(0.0194-0.1055)$ \\
\hline & $\mathrm{D}$ & - & $0.0006(0.0005-0.0008)$ & $0.0039(0.0027-0.0061)$ & $0.0096(0.0076-0.0142)$ & $0.0344(0.0256-0.0508)$ \\
\hline & Median & & 0.0016 & 0.0037 & 0.0188 & 0.0234 \\
\hline & Lifespan $^{c}$ & & 618 & 271 & 53 & 43 \\
\hline \multirow[t]{5}{*}{ cART-treated } & A & $\Delta$ & $0.0006(0.0001-0.0007)$ & $0.0002(0.0000-0.0003)$ & $0.0096(0.0057-0.0145)$ & $0.0073(0.0015-0.1275)$ \\
\hline & B & $\overline{0}$ & $0.0013(0.0009-0.0029)$ & $0.0008(0.0006-0.0023)$ & $0.0131(0.0073-0.1159)$ & $0.0499(0.0013-0.1148)$ \\
\hline & C & 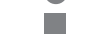 & $0.0074(0.0012-0.0856)$ & $0.0009(0.0008-0.0021)$ & $0.0158(0.0124-0.0203)$ & $0.0061(0.0016-0.1475)$ \\
\hline & Median & & 0.0013 & 0.0008 & 0.0131 & 0.0073 \\
\hline & Lifespan ${ }^{c}$ & & 769 & 1250 & 76 & 137 \\
\hline
\end{tabular}

CART, combination antiretroviral therapy.

${ }^{a}$ Estimation based on the datasets including the late samples after stop of label administration.

${ }^{\mathrm{b}} 95 \%$-confidence intervals (given in parentheses) were determined by a bootstrap method.

${ }^{\mathrm{c}}$ Median lifespan (in days) computed as $1 /$ (median turnover rate). 
patients, reached significantly higher labeling levels compared with healthy individuals (Fig. 1; individual fits are presented in Fig. S3, http://links.lww.com/ $\mathrm{QAD} / \mathrm{A760}$ ). The expected average lifespans of naive $\mathrm{CD} 4^{+}$and $\mathrm{CD}^{+}{ }^{+}$cells in treatment-naive HIV patients were 618 and 271 days, respectively, which was 3 and 12 times shorter than in healthy volunteers (Table 2 and Fig. 2a) and the expected average lifespans of memory $\mathrm{CD}^{+}$and $\mathrm{CD}^{+} \mathrm{T}$ cells were 53 and 43 days, respectively, that is, 3 times shorter than in healthy individuals (Table 2 and Fig. 2b). In contrast to our findings in healthy individuals, the labeling data of naive $\mathrm{CD}^{+} \mathrm{T}$ cells from untreated HIV-infected individuals were significantly better described by a model that allowed for kinetic heterogeneity $(P<0.01)$. Although the average per capita T-cell turnover rates of all T-cell subsets were increased in HIV infection, total naive and memory $\mathrm{CD}^{+}{ }^{+} \mathrm{T}$-cell production rates, expressed in cells per day, were not (Fig. 2c and d), which is a direct consequence of the strongly reduced $\mathrm{CD} 4^{+} \mathrm{T}$-cell counts in the blood of the untreated HIV-infected individuals included in this study $(P=0.016)$. Total naive and memory $\mathrm{CD}^{+}$T-cell production were significantly increased during HIV infection $(P=0.049$ and $P=0.032$, Fig. $2 \mathrm{c}$ and $\mathrm{d}$ ), even though naive $\mathrm{CD} 8^{+}$
T-cell counts were significantly decreased in untreated HIV-infected individuals $(P=0.016)$.

We also studied whether successful cART would lead to normalization of T-cell turnover rates in HIV-infected individuals (Table 2). Deuterium labeling curves of the different T-cell populations in the cART-treated HIVinfected individuals turned out to be close to those of healthy controls (Fig. 3; individual fits are presented in Fig. S4, http://links.lww.com/QAD/A760). Lifespans of memory $\mathrm{CD} 4^{+}$and $\mathrm{CD} 8^{+} \mathrm{T}$ cells in cART-treated HIVinfected individuals were not significantly different from those of healthy individuals (Table 2 and Fig. 2b). Although naive T-cell lifespans became closer to normal, they were still significantly shorter than in healthy volunteers $(P=0.036$, Table 2 and Fig. 2a). Consistent with our findings in healthy individuals, the labeling data of naive $\mathrm{CD}^{+}{ }^{\text {and }} \mathrm{CD} 8^{+} \mathrm{T}$ cells showed little statistical evidence for kinetic heterogeneity, whereas memory $\mathrm{CD}^{+}{ }^{+}$and $\mathrm{CD}^{+} \mathrm{T}$ cells from cART-treated individuals were significantly better described by a model that allowed for kinetic heterogeneity $(P<0.01)$. Total naive and memory $\mathrm{T}$-cell production were not significantly different between healthy and cART-treated individuals (Fig. 2c and d).

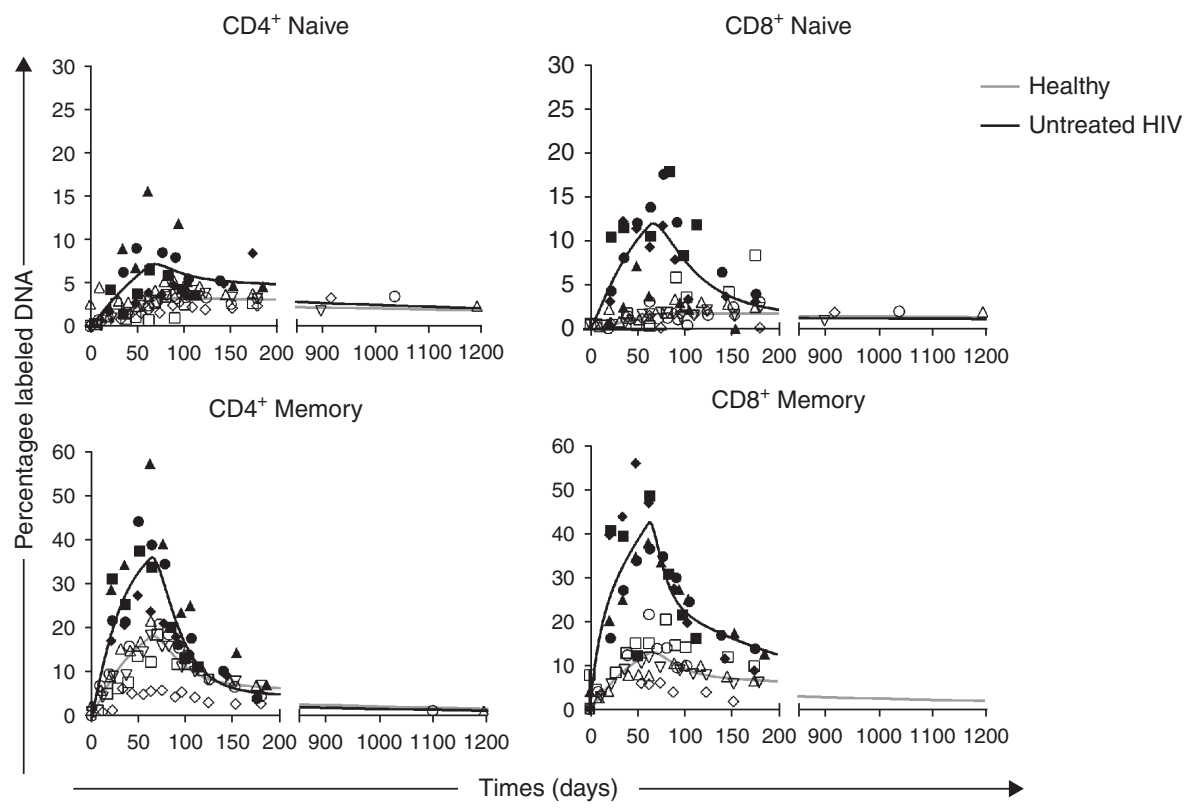

Fig. 1. ${ }^{2} \mathrm{H}$ enrichment of naive and memory $\mathrm{T}$ cells in healthy and HIV-infected individuals. Best fits of the percentage of labeled DNA in naive and memory $\mathrm{CD}^{+}$and $\mathrm{CD} 8^{+} \mathrm{T}$ cells of five healthy volunteers (open symbols, grey curves) and four untreated chronic HIV-1-infected individuals (closed symbols, black curves). For healthy volunteers, the data until day 200 were previously published in [22]; here we added samples from four of these volunteers who gave blood approximately 3 years after label cessation. The curves show the best fit of the mixed effects model to the two experimental datasets of healthy volunteers and untreated HIV-1-infected patients, including the long-term follow-up points whenever available. Label enrichment in the DNA of the different cell populations was scaled between 0 and $100 \%$ by normalizing for the estimated maximum enrichment obtained in granulocytes (see Supplemental Methods, http://links.Iww.com/QAD/A760). 
(a)

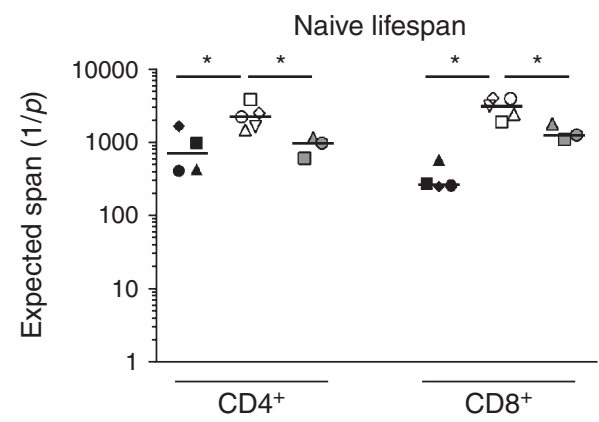

(c)

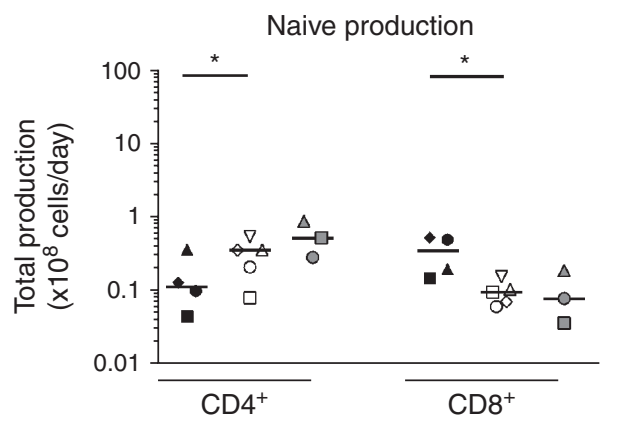

(b)

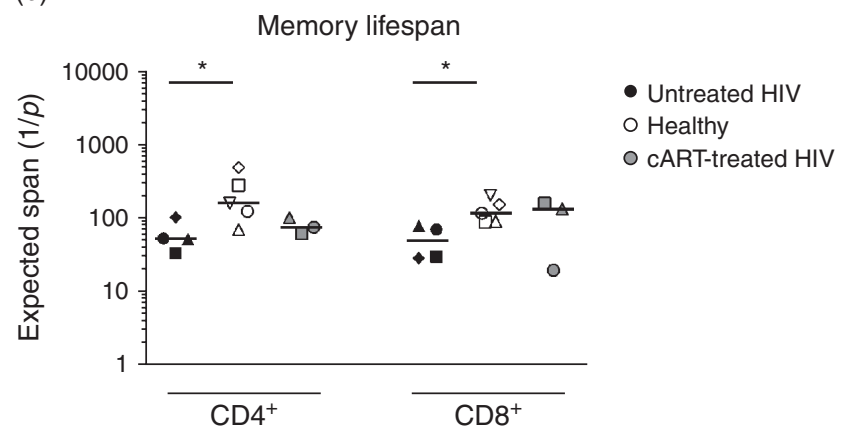

(d)

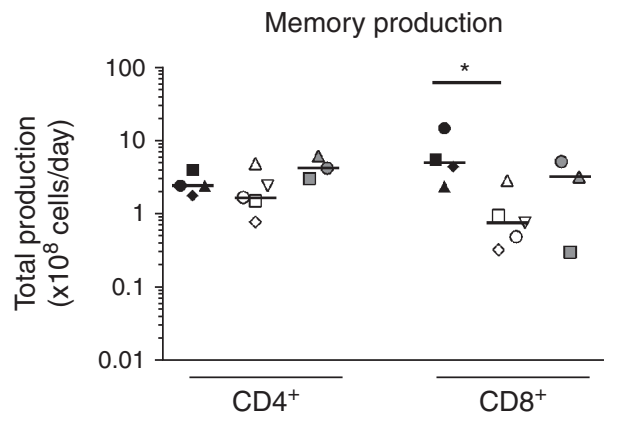

Fig. 2. Estimated T-cell lifespans and total daily production in healthy and HIV-1-infected individuals. Estimated lifespans of (a) naive and (b) memory $\mathrm{CD}^{+}$and $\mathrm{CD}^{+}{ }^{+} \mathrm{T}$ cells in untreated HIV-1-infected (closed symbols), healthy (open symbols), and combination antiretroviral therapy (CART)-treated HIV-1-infected (grey symbols) individuals, calculated from the average T-cell turnover rate $(p)$ resulting from fitting the mathematical model to the data. Total daily production (expressed in cells per day) of (c) naive and (d) memory $\mathrm{CD}^{+}$and $\mathrm{CD}^{+} \mathrm{T}$ cells in HIV-1-infected (closed symbols), healthy (open symbols) and cART-treated HIV-1-infected (grey symbols) individuals, calculated by multiplying the estimated average T-cell turnover rate ( $p$ ) with the number of $\mathrm{T}$ cells in the population under investigation.

\section{Discussion}

Long-term administration of ${ }^{2} \mathrm{H}_{2} \mathrm{O}$ and follow-up of labeled $\mathrm{T}$ cells after label cessation enabled us to reliably quantify expected lifespans and total daily T-cell production rates of naive and memory $\mathrm{CD}^{+}$and $\mathrm{CD}^{+} \mathrm{T}$ cells in healthy and HIV-infected individuals. Our data show that the average T-cell lifespans of both naive and memory $\mathrm{CD} 4^{+}$and $\mathrm{CD} 8^{+} \mathrm{T}$ cells are at least three-fold shortened during untreated, chronic HIV infection. The increased naive T-cell turnover rates that we found are in contrast to recent observations [23,24], which reported memory $\mathrm{T}$-cell turnover rates to be significantly increased whereas naive T-cell turnover rates were hardly affected by HIV-1 infection. We cannot exclude the possibility that this discrepancy is due to actual differences between the HIV-1-infected individuals who were included in the studies, as in our study HIV-infected participants had lower total CD4 ${ }^{+}$T-cell counts, and therefore might have been in more advanced stages of infection. Another clear difference between the studies is that we defined naive $\mathrm{T}$ cells by more restrictive markers, including the expression of CD27. It is very likely, however, that the most dominant factor explaining the differences between these studies is that the our 9weeks ${ }^{2} \mathrm{H}_{2} \mathrm{O}$ labeling study had a much higher sensitivity than the published 1-day labeling studies to observe differences in turnover of cells with long lifespans, such as naive $\mathrm{T}$ cells. The fact that a previous 9 -weeks ${ }^{2} \mathrm{H}_{2} \mathrm{O}$ labeling study also reported increased turnover of naive $\mathrm{T}$ cells in HIV [16] supports this view. The increased naive and memory T-cell per capita turnover rates that we observed are also consistent with the increased levels of Ki67 expression that have been observed in T cells during HIV infection [31]. Remarkably, we found that naive T-cell turnover rates tended not to normalize in HIV-1infected individuals on successful cART, although they were clearly lower than in untreated HIV-infected individuals. Memory T-cell turnover rates in contrast tended to normalize on successful cART. Of note, the differences in time on cARTwere quite large between our patients, varying from 1 to 15 years. Even though based on very few treated patients, we found that cellular turnover rates correlated with time on cART, as previously suggested by labeling studies after short-term and long-term cART $[11,22]$.

Almost all other published labeling studies in HIVinfected individuals have quantified turnover of total $\mathrm{CD}^{+}$and total $\mathrm{CD}^{+}{ }^{+} \mathrm{T}$ cells, and have reported increased rates of T-cell turnover compared with healthy individuals $[9,11,16,22,32,12]$. As we measured 


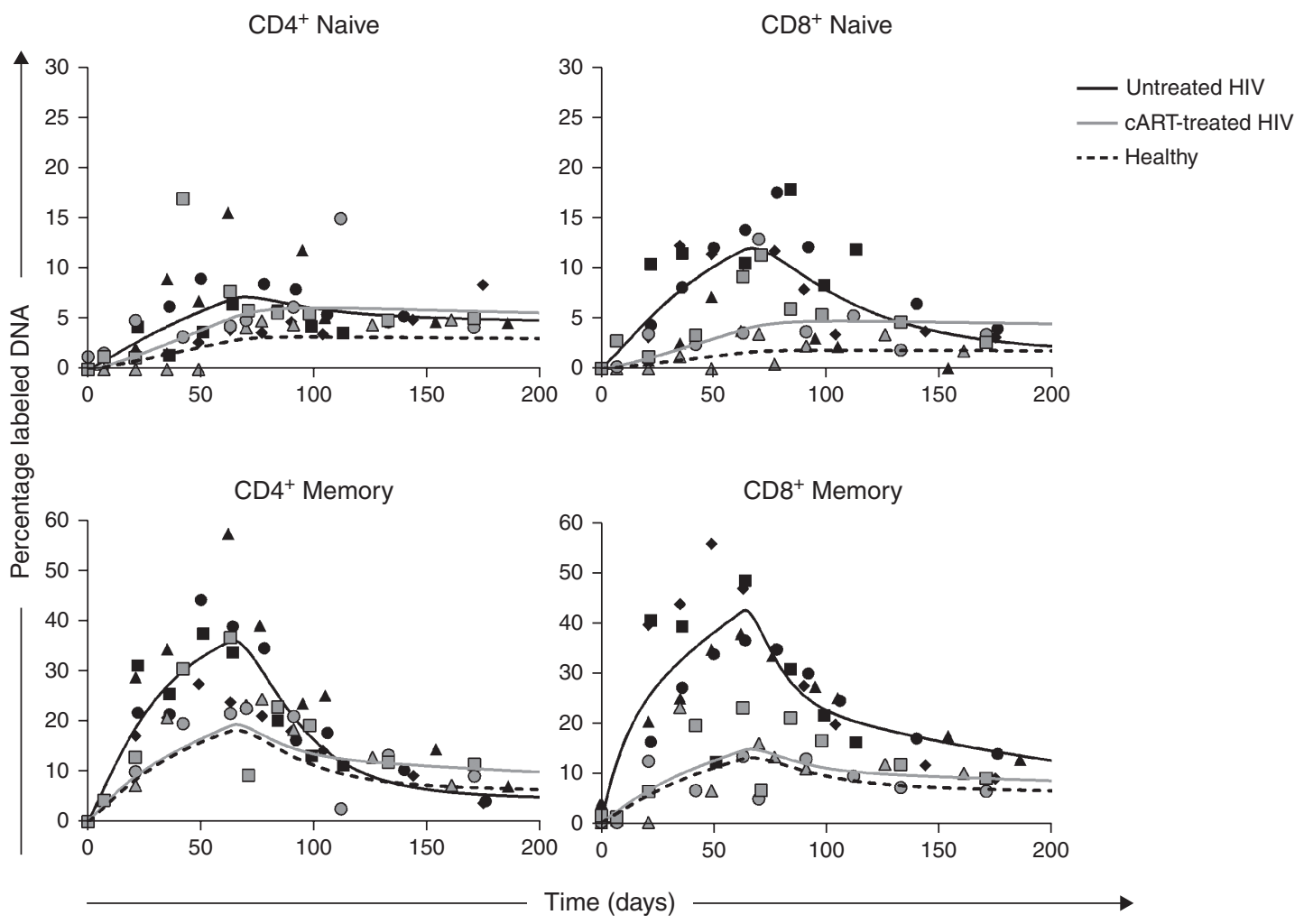

Fig. 3. ${ }^{2} \mathrm{H}$ enrichment of naive and memory $\mathrm{T}$ cells of combination antiretroviral therapy (cART)-treated and treatment-naive HIV-infected individuals. Best fits of the percentage of labeled DNA in naive and memory $\mathrm{CD} 4^{+}$and $\mathrm{CD} 8^{+} \mathrm{T}$ cells of four treatment-naive HIV-infected individuals (black symbols and curves) and three cART-treated HIV-infected individuals with a good virological and immunological response to treatment (grey symbols and curves). For reference, the best fit through the data from healthy volunteers (Fig. 1) is plotted as a dashed curve. The curves show the best fit of the mixed effects model to the experimental data. Label enrichment in the DNA of the different cell populations was scaled between 0 and $100 \%$ by normalizing for the estimated maximum enrichment obtained in granulocytes (see Supplemental Methods, http://links.Iww.com/QAD/A760).

deuterium enrichment in sorted naive and memory T-cell subsets, our results cannot directly be compared with such studies. For three of the untreated HIV-infected individuals (A, B, and C), however, we could estimate the expected enrichment in total $\mathrm{CD}^{+} \mathrm{T}$ cells as previously described [30,33] because their naive and memory phenotype cells together constituted $\sim 95 \%$ of their total $\mathrm{CD} 4^{+}$T-cell pool. The indirectly estimated average lifespans of $\mathrm{CD} 4^{+} \mathrm{T}$ cells in these three untreated HIV-infected individuals were consistently longer compared with most previously published estimates, although in line with one previous long-term labeling study [16] (Table S1 and S2, http://links.lww.com/QAD/A760). Differences in patient characteristics, including their naive/memory T-cell ratios, total $\mathrm{CD} 4^{+}$T-cell counts, HIV viral load, and clinical stage may have contributed to these differences in the lifespans. Another factor that likely underlies these differences is related to the study protocol. We have previously shown that in healthy individuals, short-term deuterated glucose labeling studies tended to yield shorter T-cell lifespan estimates than long-term ${ }^{2} \mathrm{H}_{2} \mathrm{O}$ labeling studies [34]. The effect of the duration of label administration can be circumvented by using multiexponential models [30], as we did here.
The fact that we still estimated consistently longer T-cell life expectancies than published estimates is probably related to the difficulty of estimating deuterium availability in short-term deuterated glucose labeling studies, as glucose is highly dynamic, a problem that is much less severe in ${ }^{2} \mathrm{H}_{2} \mathrm{O}$ labeling studies [35]. Importantly, our long-term follow-up of ${ }^{2} \mathrm{H}_{2} \mathrm{O}$-labeled healthy individuals showed that deuterium enrichment was still present in naive $\mathrm{T}$ cells up to 3.5 years after label cessation, confirming the long T-cell lifespan estimates based on ${ }^{2} \mathrm{H}_{2} \mathrm{O}$ labeling. We therefore regard our T-cell lifespan estimates of $\sim 600$ days for naive $\mathrm{CD} 4^{+} \mathrm{T}$ cells, $\sim 300$ days for naive $\mathrm{CD}^{+} \mathrm{T}$ cells, and $\sim 50$ days for memory $\mathrm{CD} 4^{+}$ and $\mathrm{CD}^{+} \mathrm{T}$ cells as the currently best estimates in treatment-naive HIV patients.

Elevated T-cell production rates in HIV-infected patients have been proposed to reflect either a homeostatic response to compensate for the progressive loss of $\mathrm{CD} 4^{+} \mathrm{T}$ cells $[36,37]$ or to be driven by immune activation [31]. It has previously been shown that HIV-infected patients suffering from AIDS have increased levels of interleukin-7 (IL-7) production in lymphoid tissue [38], and that naive T cells can divide in response to IL-7 while retaining the naive 
phenotype $[39,40]$, suggesting that homeostatic T-cell proliferation may occur in HIV infection. In line with this, a recent study based on in-vivo BrdU labeling found that naive $\mathrm{CD}^{+}{ }^{+}$T-cell turnover rates in HIV patients correlated significantly with $\mathrm{CD}^{+}{ }^{+}$T-cell counts, but not with HIV viral load [41]. Alternatively, both the acute, drastic loss of memory $\mathrm{CD}^{+} \mathrm{T}$ cells from the gastrointestinal tract, which causes translocation of microbial products from the gut into the blood of HIVinfected individuals [42], and the direct activation of Tolllike receptors by HIV [43,44] may be drivers of the observed activation of the naive T-cell pool during HIV infection. The observation that cART strongly decreases the percentage of Ki67-expressing $\mathrm{CD}^{+} \mathrm{T}$ cells long before $\mathrm{CD} 4{ }^{+}$T-cell numbers have normalized, suggests that increased T-cell production rates in HIV infection are to a large extent driven by the effects of the virus, rather than by a homeostatic response to low $\mathrm{CD}^{+}{ }^{+}$T-cell numbers $[45,46]$. We therefore tend to interpret the at least three-fold higher T-lymphocyte turnover rates in HIVinfected individuals that we reported here as an immune stimulatory effect of the virus.

Our analyses also point at qualitative changes in the kinetics of the naive T-cell pool of HIV-infected individuals. Whereas in healthy individuals, naive $\mathrm{T}$ cells form a kinetically homogeneous pool of cells that are extremely long-lived, upon HIV infection a significant subset of naive $\mathrm{T}$ cells acquires a high rate of turnover. During the entire follow-up period, naive T-cell numbers nevertheless stayed relatively constant in all HIV-infected individuals, because naive $\mathrm{T}$ cells with relatively short expected lifespans were produced at increased rates. It is important to realize that the interpretation of the sizes $\alpha_{\mathrm{i}}$ and turnover rates $p_{\mathrm{i}}$ of the subpopulations delivered by the model is not straightforward. The uncertainty on these parameters tends to be larger than on the average turnover rate $p$ (Figure S5, http://links.lww.com/QAD/ A760), because of the strong correlation between the size of a subpopulation and its turnover rate [30]. Additionally, the subpopulations used in the model need not reflect phenotypically different subsets, and an alternative interpretation for kinetic heterogeneity is that $\mathrm{T}$ cells transiently have different turnover rates, for example, resting cells and cells that have recently been produced or activated may have different life expectancies [30].

The role of the thymus in the altered dynamics of naive $\mathrm{T}$ cells during HIV-1 infection is still debated $[11,31,36,47]$. Using mathematical modeling it has been shown that the observed relatively rapid dilution of the average T-cell receptor excision circle (TREC) content of naive T cells in HIV-infected individuals [47] cannot be explained by changes in thymic output alone [48] if naive $\mathrm{T}$ cells are long-lived. Our long-term follow-up of ${ }^{2} \mathrm{H}_{2} \mathrm{O}$-labeled individuals confirms that under healthy circumstances naive $\mathrm{CD}^{+}{ }^{+}$and $\mathrm{CD}^{+}{ }^{+} \mathrm{T}$ cells are indeed very longlived, with expected lifespans as long as 5.6 and 8.8 years, respectively. It has been rightly argued that these modeling results hinge upon the assumption that all naive $\mathrm{T}$ cells have the same kinetic behavior [36]. If instead, the naive T-cell pool were to contain a subpopulation of short-lived recent thymic emigrant (RTE), as has been observed in mice $[49,50]$, the average TREC content of naive may be rapidly affected when thymic output is blocked by HIV [36]. Our ${ }^{2} \mathrm{H}_{2} \mathrm{O}$ labeling data from healthy volunteers show, however, that human naive $\mathrm{T}$ cells form a kinetically homogeneous population of long-lived cells, arguing against the presence of a substantial RTE population with rapid kinetics in healthy adults [22], and thereby showing that blockade of thymic output does not suffice to explain the lowered TREC contents observed in HIV infection. Instead, TREC dilution in HIV infection is presumably caused by the state of chronic immune activation induced by the virus [31] (Drylewicz et al. submitted).

\section{Acknowledgements}

The authors greatly acknowledge Marc Hellerstein and Rich Neese for sharing the ${ }^{2} \mathrm{H}_{2} \mathrm{O}$ labeling and GC-MS protocols, Mette D. Hazenberg for her help in designing and implementing the study protocol, An Ruiter, Koos Gaiser and Anne Bregje de Boer for technical support and Inge de Kroon for logistical support.

This research has been funded by AIDS Fonds Netherlands (grants 4025, 4024, 7010), the Netherlands Organization for Scientific Research (NWO, grants 016.048.603, 917.96.350, 836.07.002), and the VIRGO consortium funded by the Dutch government (project number FES0908) and by the Netherlands Genomics Initiative (project number 050-060-452).

N.V., J.D., R.vG., R.J.deB., K.T., and J.A.M.B. wrote the manuscript; N.V., R.vG., F.M., K.T., and J.A.M.B. designed the study; S.F.L.vL., J.N.V., H.H.H., M.T.A. and J.M.P. were responsible for patient inclusion and logistics; N.V., R.vG., E.V. performed the experiments; J.D., T.M., R.J.deB. and J.A.M.B. performed statistical analyses and mathematical modeling. All authors were involved in data interpretation and critically reviewed and subsequently approved the final version.

\section{Conflicts of interest}

The authors have no conflicts of interest.

\section{References}

1. Choudhary SK, Vrisekoop N, Jansen CA, Otto SA, Schuitemaker $\mathrm{H}$, Miedema $\mathrm{F}$, et al. Low immune activation despite high levels of pathogenic human immunodeficiency virus type 1 results in long-term asymptomatic disease. J Virol 2007; 81:8838-8842. 
2. Deeks SG, Kitchen CM, Liu L, Guo H, Gascon R, Narvaez AB, et al. Immune activation set point during early HIV infection predicts subsequent CD4+ T-cell changes independent of viral load. Blood 2004; 104:942-947.

3. Giorgi JV, Hultin LE, McKeating JA, Johnson TD, Owens B, Jacobson LP, et al. Shorter survival in advanced human immunodeficiency virus type 1 infection is more closely associated with T lymphocyte activation than with plasma virus burden or virus chemokine coreceptor usage. J Infect Dis 1999; 179:859-870.

4. Hazenberg MD, Otto SA, van Benthem BH, Roos MT, Coutinho RA, Lange JM, et al. Persistent immune activation in HIV-1 infection is associated with progression to AIDS. AIDS 2003; 17:1881-1888

5. Silvestri G, Sodora DL, Koup RA, Paiardini M, O'Neil SP, McClure HM, et al. Nonpathogenic SIV infection of sooty mangabeys is characterized by limited bystander immunopathology despite chronic high-level viremia. Immunity 2003; 18:441-452.

6. Ferguson NM, deWolf F, Ghani AC, Fraser C, Donnelly CA, Reiss $\mathrm{P}$, et al. Antigen-driven CD4+ T cell and HIV-1 dynamics: residual viral replication under highly active antiretroviral therapy. Proc Natl Acad Sci U S A 1999; 96:1516715172.

7. Hellerstein M, Hanley MB, Cesar D, Siler S, Papageorgopoulos $\mathrm{C}$, Wieder $\mathrm{E}$, et al. Directly measured kinetics of circulating $\mathbf{T}$ lymphocytes in normal and HIV-1-infected humans. Nat Med 1999; 5:83-89.

8. Kovacs JA, Lempicki RA, Sidorov IA, Adelsberger JW, Herpin B, Metcalf JA, et al. Identification of dynamically distinct subpopulations of $\mathrm{T}$ lymphocytes that are differentially affected by HIV. J Exp Med 2001; 194:1731-1741.

9. Kovacs JA, Lempicki RA, Sidorov IA, Adelsberger JW, Sereti I, Sachau W, et al. Induction of prolonged survival of CD4+ T lymphocytes by intermittent IL-2 therapy in HIV-infected patients. J Clin Invest 2005; 115:2139-2148.

10. Lempicki RA, Kovacs JA, Baseler MW, Adelsberger JW, Dewar $\mathrm{RL}$, Natarajan $\mathrm{V}$, et al. Impact of HIV-1 infection and highly active antiretroviral therapy on the kinetics of $\mathrm{CD4}^{+}$and $\mathrm{CDB}^{+}$ T cell turnover in HIV-infected patients. Proc Natl Acad SCi U S A 2000; 97:13778-13783.

11. McCune JM, Hanley MB, Cesar D, Halvorsen R, Hoh R, Schmidt $\mathrm{D}$, et al. Factors influencing T-cell turnover in HIV-1-seropositive patients. J Clin Invest 2000; 105:R1-R8.

12. Mohri H, Perelson AS, Tung K, Ribeiro RM, Ramratnam B, Markowitz $M$, et al. Increased turnover of $\mathbf{T}$ lymphocytes in HIV-1 infection and its reduction by antiretroviral therapy. J Exp Med 2001; 194:1277-1287.

13. Perelson AS, Essunger P, Ho DD. Dynamics of HIV-1 and CD4 $^{+}$lymphocytes in vivo. AIDS 1997; 11 (Suppl A):S17$\mathrm{S} 24$.

14. Sachsenberg N, Perelson AS, Yerly S, Schockmel GA, Leduc D, Hirschel B, et al. Turnover of CD4 ${ }^{+}$and $\mathrm{CDB}^{+}$T lymphocytes in HIV-1 infection as measured by Ki-67 antigen. / Exp Med 1998; 187:1295-1303.

15. Roederer M, Dubs JG, Anderson MT, Raju PA, Herzenberg LA, Herzenberg LA. CD8 naive T cell counts decrease progressively in HIV-infected adults. / Clin Invest 1995; 95:20612066.

16. Hellerstein MK, Hoh RA, Hanley MB, Cesar D, Lee D, Neese RA, et al. Subpopulations of long-lived and short-lived T cells in advanced HIV-1 infection. J Clin Invest 2003; 112:956-966.

17. Combadere B, Blanc C, Li T, Carcelain G, Delaugerre C, Calvez $\mathrm{V}$, et al. CD4+Ki67+ lymphocytes in HIV-infected patients are effector T cells accumulated in the G1 phase of the cell cycle. Eur I Immunol 2000; 30:3598-3603.

18. Ladell K, Hellerstein MK, Cesar D, Busch R, Boban D, McCune JM. Central memory CD8+ T cells appear to have a shorter lifespan and reduced abundance as a function of HIV disease progression. I Immunol 2008; 180:7907-7918.

19. Macallan DC, Asquith B, Irvine AJ, Wallace DL, Worth A, Ghattas $\mathrm{H}$, et al. Measurement and modeling of human $\mathrm{T}$ cell kinetics. Eur I Immunol 2003; 33:2316-2326.

20. Macallan DC, Wallace D, Zhang Y, De LC, Worth AT, Ghattas $\mathrm{H}$, et al. Rapid turnover of effector-memory CD4(+) T cells in healthy humans. J Exp Med 2004; 200:255-260.
21. Ribeiro RM, Mohri H, Ho DD, Perelson AS. In vivo dynamics of $T$ cell activation, proliferation, and death in HIV-1 infection: why are CD4+ but not CD8+ T cells depleted? Proc Natl Acad Sci U S A 2002; 99:15572-15577.

22. Vrisekoop N, den Braber I, de Boer AB, Ruiter AF, Ackermans MT, van der Crabben SN, et al. Sparse production but preferential incorporation of recently produced naive $T$ cells in the human peripheral pool. Proc Natl Acad Sci U S A 2008; 105:6115-6120.

23. Zhang Y, De Lara C, Worth A, Hegedus A, Laamanen K, Beverley $\mathrm{P}$, et al. Accelerated in vivo proliferation of memory phenotype CD4(+) T-cells in human HIV-1 infection irrespective of viral chemokine co-receptor tropism. PLoS Pathog 2013; 9:e1003310.

24. Hegedus A, Nyamweya S, Zhang Y, Govind S, Aspinall R, Mashanova $A$, et al. Protection versus pathology in aviremic and high viral load HIV-2 infection-the pivotal role of immune activation and T-cell kinetics. I Infect Dis 2014; 210:752761.

25. Watson PE, Watson ID, Batt RD. Total body water volumes for adult males and females estimated from simple anthropometric measurements. Am J Clin Nutr 1980; 33:27-39.

26. Westera L, Zhang Y, Tesselaar K, Borghans JA, Macallan DC. Quantitating lymphocyte homeostasis in vivo in humans using stable isotope tracers. Methods Mol Biol 2013; 979:107-131.

27. Neese RA, Misell LM, Turner S, Chu A, Kim J, Cesar D, et al. Measurement in vivo of proliferation rates of slow turnover cells by ${ }^{2} \mathrm{H}_{2} \mathrm{O}$ labeling of the deoxyribose moiety of DNA. ProC Natl Acad Sci U S A 2002; 99:15345-15350.

28. Previs SF, Des RC, Beylot M, David F, Brunengraber H. Assay of the ${ }^{13} \mathrm{C}$ and ${ }^{2} \mathrm{H}$ mass isotopomer distribution of phosphoenolpyruvate by gas chromatography/mass spectrometry. I Mass Spectrom 1996; 31:643-648.

29. Ganusov V, Borghans JAM, De Boer RJ. Explicit kinetic heterogeneity: mathematical models for interpretation of deuterium labeling of heterogeneous cell populations. PLoS Comput Biol 2010; 6:e1000666.

30. Westera L, Drylewicz J, den Braber I, Mugwagwa T, van der Maas I, Kwast L, et al. Closing the gap between T-cell life span estimates from stable isotope-labeling studies in mice and humans. Blood 2013; 122:2205-2212.

31. Hazenberg MD, Stuart JW, Otto SA, Borleffs JC, Boucher CA, de Boer RJ, et al. T-cell division in human immunodeficiency virus (HIV)-1 infection is mainly due to immune activation: a longitudinal analysis in patients before and during highly active antiretroviral therapy (HAART). Blood 2000; 95:249-255.

32. Hellerstein M, Hanley MB, Cesar D, Siler S, Papageorgopoulos C, Wieder $\mathrm{E}$, et al. Directly measured kinetics of circulating $\mathbf{T}$ lymphocytes in normal and HIV-1 infected humans. Nature Med 1999; 5:83-89.

33. De Boer RJ, Perelson AS. Quantifying T lymphocyte turnover. J Theor Biol 2013; 327:45-87.

34. Borghans JA, De Boer RJ. Quantification of T-cell dynamics: from telomeres to DNA labeling. Immunol Rev 2007; 216:3547.

35. Ahmed R, Westera L, Drylewicz J, Elemans M, Zhang Y, Kelly E, et al. Reconciling estimates of cell proliferation from stable isotope labeling experiments. PLOS Comp Biol 2015 doi:10.1371/journal.pcbi.1004355.

36. Dion ML, Poulin JF, Bordi R, Sylvestre M, Corsini R, Kettaf N, et al. HIV infection rapidly induces and maintains a substantial suppression of thymocyte proliferation. Immunity 2004; 21:757768.

37. Ho DD, Neumann AU, Perelson AS, Chen W, Leonard JM, Markowitz M. Rapid turnover of plasma virions and CD4 lymphocytes in HIV-1 infection. Nature 1995; 373:123-126.

38. Napolitano LA, Grant RM, Deeks SG, Schmidt D, De Rosa SC, Herzenberg LA, et al. Increased production of IL-7 accompanies HIV-1-mediated T-cell depletion: implications for T-cell homeostasis. Nat Med 2001; 7:73-79.

39. Soares MV, Borthwick NJ, Maini MK, Janossy G, Salmon M, Akbar AN. IL-7-dependent extrathymic expansion of CD45RA + T cells enables preservation of a naive repertoire. I Immunol 1998; 161:5909-5917.

40. Steffens CM, Managlia EZ, Landay A, Al-Harthi L. Interleukin-7treated naive $\mathrm{T}$ cells can be productively infected by T-celladapted and primary isolates of human immunodeficiency virus 1. Blood 2002; 99:3310-3318. 
41. Srinivasula S, Lempicki RA, Adelsberger JW, Huang CY, Roark J, Lee PI, et al. Differential effects of HIV viral load and CD4 count on proliferation of naive and memory CD4 and CD8 T lymphocytes. Blood 2011; 118:262-270.

42. Brenchley JM, Price DA, Schacker TW, Asher TE, Silvestri G, Rao $S$, et al. Microbial translocation is a cause of systemic immune activation in chronic HIV infection. Nat Med 2006; 12:1365-1371.

43. Herbeuval JP, Boasso A, Grivel JC, Hardy AW, Anderson SA, Dolan MJ, et al. TNF-related apoptosis-inducing ligand (TRAIL) in HIV-1-infected patients and its in vitro production by antigen-presenting cells. Blood 2005; 105:2458-2464.

44. Boasso A, Shearer GM. Chronic innate immune activation as a cause of HIV-1 immunopathogenesis. Clin Immunol 2008; 126:235-242.

45. Hazenberg MD, Hamann D, Schuitemaker $\mathrm{H}$, Miedema F. T cell depletion in HIV-1 infection: how $\mathrm{CD4}^{+} \mathrm{T}$ cells go out of stock. Nat Immunol 2000; 1:285-289.
46. Miedema F, Hazenberg MD, Tesselaar K, van Baarle D, De Boer $\mathrm{RJ}$, Borghans JA. Immune activation and collateral damage in AIDS pathogenesis. Front Immunol 2013; 4:298.

47. Douek DC, McFarland RD, Keiser PH, Gage EA, Massey JM, Haynes BF, et al. Changes in thymic function with age and during the treatment of HIV infection. Nature 1998; 396:690695.

48. Hazenberg MD, Otto SA, Cohen Stuart JWT, Verschuren MCM Borleffs JCC, Boucher CAB, et al. Increased cell division but not thymic dysfunction rapidly affects the TREC content of the naive T cell population in HIV-1 infection. Nat Med 2000; 6:1036-1042.

49. Berzins SP, Boyd RL, Miller JF. The role of the thymus and recent thymic migrants in the maintenance of the adult peripheral lymphocyte pool. J Exp Med 1998; 187:1839-1848.

50. Berzins SP, Godfrey DI, Miller JF, Boyd RL. A central role for thymic emigrants in peripheral T cell homeostasis. Proc Natl Acad Sci U S A 1999; 96:9787-9791. 